T II E L A B O R O F D E V E L O P II E N T 


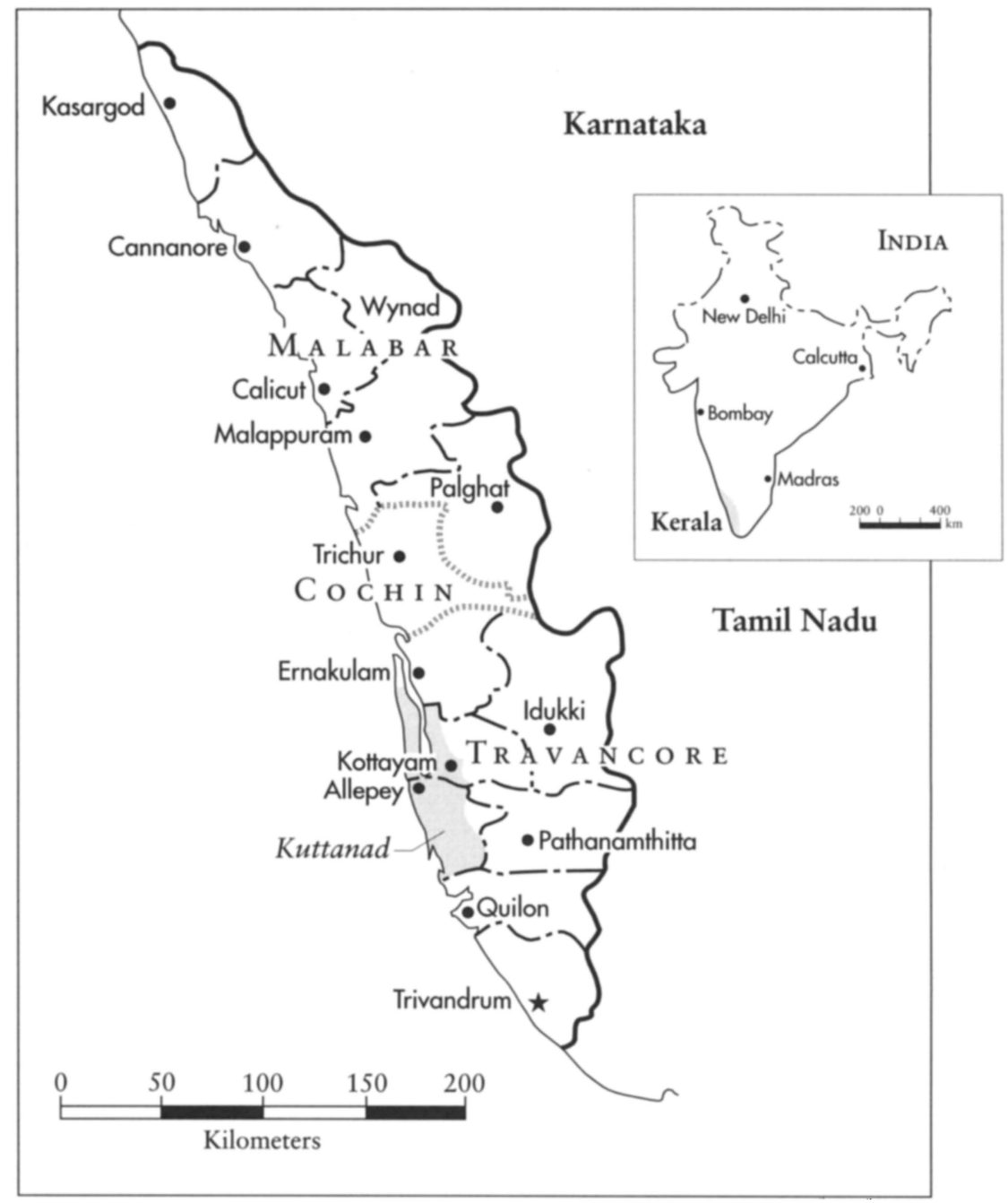




\section{The Labor of Development}

Workers and the Transformation of Capitalism in Kerala, India

\section{PATRICK HELLER}

CORNELL UNIVERSITY PRESS

Ithaca and London 


\section{Copyright @ 1999 by Cornell University}

All rights reserved. Except for brief quotations in a review, this book, or parts thereof, must not be reproduced in any form without permission in writing from the publisher. For information, address Cornell University Press, Sage House, 512 East State Street, Ithaca, New York 14850.

First published 1999 by Cornell University Press

First printing,Cornell Paperbacks, 1999

Printed in the United States of America

Library of Congress Cataloging-in-Publication Data

Heller, Patrick.

The labor of development : workers and the transformation of capitalism in Kerala, India / Patrick Heller.

p. $\mathrm{cm}$.

Includes bibliographical references and index.

ISBN: 0-8014-3590-0 (cloth). - ISBN 0-8014-8624-6 (pbk.)

1. Labor movement-India-Kerala-History. 2. Labor unionsIndia-Kerala-History. 3. Working class-India-Kerala-History. 4. Peasantry-India-Kerala-History. 5. Agriculture-Economic aspects-India-Kerala-History. 6. Kerala (India)-Economic conditions. I. Title HD8689.K452H45 1999

$331.88^{\prime} 0954^{\prime} 83-\mathrm{dc} 21 \quad 99-43546$

Cornell University Press strives to use environmentally responsible suppliers and materials to the fullest extent possible in the publishing of its books. Such materials include vegetable-based, low-VOC inks and acid-free papers that are recycled, totally chlorine-free, or partly composed of nonwood fibers. Books that bear the logo of the FSC (Forest Stewardship Council) use paper taken from forests that have been inspected and certified as meeting the highest standards for environmental and social responsibility. For further information, vist our website at www.cornellpress.cornell.edu.

$$
\begin{array}{ccccccccccccc}
\text { Cloth printing } & 10 & 9 & 8 & 7 & 6 & 5 & 4 & 3 & 2 & 1 \\
\text { Paperback printing } & 10 & 9 & 8 & 7 & 6 & 5 & 4 & 3 & 2 & 1
\end{array}
$$




\section{To Max and Rosemarie Heller}


